\title{
Gi meg lyset
}

\section{| 1890-årene introduserte den danske} legen Niels Finsen (1860-1904) medisinsk lysbehandling. Det var derfor et godt valg å spørre Søren Krøyer (1851-1909), en lysets mester, om å male Finseninstituttets lyssal. Men Krøyer var syk, og oppdraget ble dessverre aldri fullført.

\section{Erlend Hem}

erlend.hem@medisin.uio.no Tidsskriftet

Den norskfødte maleren Peder Severin (Søren) Krøyer var et stort navn i dansk malerkunst da han mottok bestilling på et figurmaleri fra instituttet. Bestillingen resulterte imidlertid aldri i mer enn to skisser, som kunstneren utførte i 1903 (1). Grunnen til at arbeidet stoppet opp, var at Krøyer var syk. I 1900 ble han første gang innlagt i mentalsykehus. Man har antatt at han led av dementia paralytica, siste stadium av syfilis, men det stemmer nok ikke. Han var kognitivt adekvat til det siste. Symptombildet er heller forenlig med en bipolar lidelse (2-5). I 1903 begynte sykdommen å vanskeliggjøre selv de mest opplagte oppgaver. Han var innlagt for andre gang ved Middelfart asyl i perioden oktober 1903mai 1904. Nederlagene hopet seg opp både $\mathrm{i}$ hans kunstneriske karriere, og $\mathrm{i}$ det liv «der havde ham selv som et mere og mere flakkende centrum» (1). Det største slaget var nok at hjemmet ble oppløst, hustruen Marie (1867-1940) forlot ham til fordel for komponisten Hugo Alfvén (1872-1960).

Maleriet av Finseninstituttets lyssal skulle ha vært en figurrik fremstilling, hvor man kunne finne alle de personer som hadde tilknytning til instituttet eller hadde sitt dag- lige arbeid i det store søylebårne rommet med to tønnehvelv (1). I presentasjonen av pastellen på Frederiksborgmuseets nettside oppgis hele 31 navn (6) (fig 1).

Pastellen viser hvordan Krøyer hadde bygd opp komposisjonen med instituttets ledelse til venstre i forgrunnen. Professoren Niels Finsen står i midten i hvit frakk, mens sykepleierne og de syke er spredd i et langt perspektiv gjennom rommet. Det er her behandlingen foregår ved intens bestråling. Sykepleierne som bærer briller, kalles «lysalfer». Ned fra taket henger konstruksjonene med de mørke skjermene og kullbuelampene. Kontrasten mellom de to lyskildene er tydelig: dagslyset fra de fire store vinduene og kullbuelampenes lys bak de røde forhengene. Krøyer har neppe kunnet ønske seg det bedre (1).

Niels Ryberg Finsen fikk nobelprisen for å ha innført «konsentrerte lysstråler» i medisinsk behandling, særlig ved hudtuberkulose (lupus vulgaris) $(7,8)$. I 1896 hadde han etablert et eget lysinstitutt, som

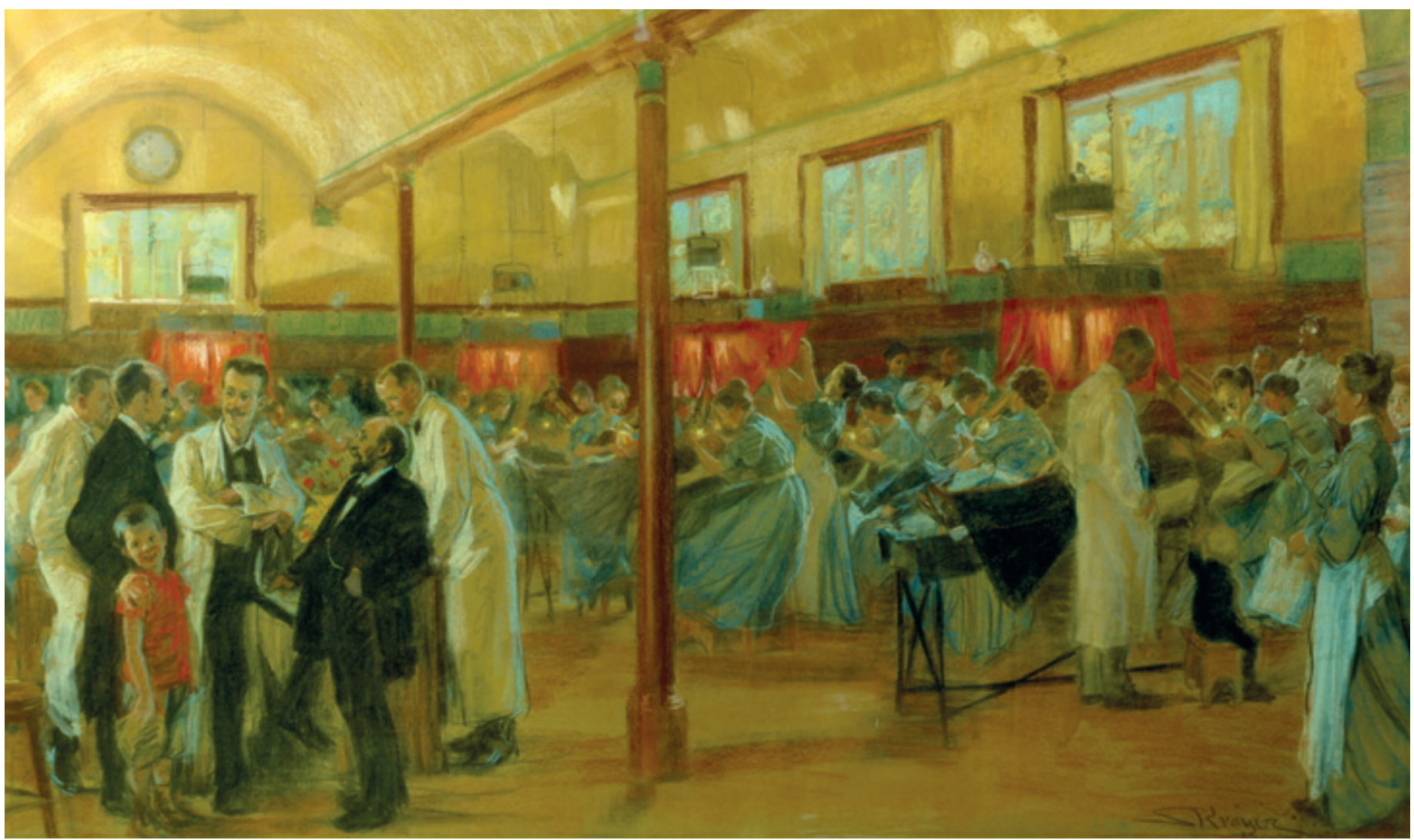

Figur 1 Finsens medicinske Lysinstitut. Skisse av Søren Krøyer, 1903. Pastell, 113,9 x 185,2 cm. Bestilt av ingeniør Gustav Adolph Hagemann (1842-1916), som er den svartkledde mannen i forgrunnen. Han var på denne tiden dansk industris ukronte konge (1). Til venstre for Hagemann ses Niels Finsen med korslagte armer og til venstre for Finsen står ingeniør Vilhelm Jørgensen (1844-1925), som sammen med Hagemann var instituttets mesener. Tilhører Det Nationalhistoriske Museum på Frederiksborg Slot 
i 1901 flyttet til større bygninger på Østerbro. I tillegg til den sykdomsrammede kunstneren og det medisinske motivet er det enda et medisinsk poeng knyttet til bildet. Da nobelprisen ble utdelt i desember 1903 var Niels Finsen for syk til å hente den. Han døde allerede året etter, 44 år gammel. I mange omtaler av Finsen står det at han døde av Picks sykdom. Det er forvirrende for moderne lesere, fordi dette sykdomsnavnet $i$ dag brukes $i$ andre sammenhenger. På begynnelsen av 1900-tallet var Picks sykdom betegnelsen på konstriktiv perikarditt, oppkalt etter den tyske legen Friedel Pick (1867-1926) (9).

Det er neppe tvil om at Finsens lysbehandling hadde effekt. Dessuten var den bortimot smertefri og etterlot ingen arr. Finsen eksperimenterte med forskjellige typer lys, ulike linser etc, og mente at lyset drepte tuberkelbasillene (10). Finsens lysbehandling ble anvendt lenge etter hans død, også i Norge. Først i begynnelsen av 1970-årene ble «Finsenavdelingen» ved Rikshospitalets hudavdeling nedlagt, over 20 år etter introduksjonen av kjemoterapi ved lupus vulgaris (7).

Oppgitte interessekonflikter: Ingen

\section{Litteratur}

1. Hornung PM. Peder Severin Krøyer. København: Forlaget Palle Fogtdal, 2005: 336-9.

2. Søgaard I. P. S. Krøyers sygdom - dementia paralytica eller maniodepressiv psykose? Bibl Læger 1997: 189: 337-72

3. Søgaard I. P. S. Krøyers sindssygdom. Vendsyssel Årbog 1998. Vendsyssel: Historisk Samfund for Vendsyssel, 1998: 31-64.

4. Strandjord RE. Peder Severin Krøyer: fra Den kombinerede Indretning til Middelfart Sindsygehus. I: Dietrichs E, Stien R, red. Hjernen og kulturen. Oslo: Koloritt forlag, 2006: 77-96.

5. Harris JC. Summer evening on the beach at Skagen: the artist and his wife. Arch Gen Psychiatry 2009; 66: 580. http://archpsyc. ama-assn.org/cgi/content/full/66/6/580 (22.2.2010).

6. Frederiksborgmuseet online. http://katalog. frederiksborgmuseet.dk/frameset.htm (22.2.2010).

7. Fyrand O. Finsens lysterapi. Anmeldelse av: Lyngbye J. Lyssagen. Tidsskr Nor Lægeforen 2004; 124: 1272 .

8. Hansen SL. Forskeren som helt: læsninger af fire biografier om tuberkuloseforskeren Niels Finsen (1860-1904). Bibl Læger 2005; 197: 4-76.

9. Friedel J. Pick. www.whonamedit.com/doctor.cfm/ 2332.html (5.5.2010)

10. Møller KI, Kongshoj B. Philipsen PA et al. How Finsen's light cured lupus vulgaris. Photodermatol Photoimmunol Photomed 2005; 21: 118-24. 